\title{
Debt Renegotiation With Incomplete Contract
}

Paulo de Melo Jorge Neto
Professor do Programa de Pós-graduação em Economia (CAEN)

- Universidade Federal do Ceará (UFC)

\begin{abstract}
RESUMO
Um contrato de débito geralmente não inclui uma cláusula sobre renegociação. $O$ direito de liquidar os ativos do tomador e as regras do processo são habitualmente estipuladas no contrato. Tal promessa de não renegociar não é crível, já que a renegociação pode mitigar a perda bruta de se liquidar tomadores insolventes. Uma vez que o contrato inicial pode não considerar os procedimentos de renegociação, e esta pode, de fato, vir a ocorrer, este artigo investiga a razão de um contrato completo não ser ofertado. Mostra-se que o emprestador não precisa estipular os procedimentos de renegociação no contrato inicial porque ele é indiferente entre se comprometer ou não aos termos do contrato. Isto indica que um contrato completo dá ao emprestador o mesmo retorno esperado de um contrato incompleto, no qual os procedimentos de renegociação são determinados após a declaração de default.
\end{abstract}

\section{PALAVRAS-CHAVE}

contrato incompleto, contrato de débito, renegociação

A debt contract usually does not include a provision about renegotiation. The right to seize the borrower's asset and the rules of this process are usually stipulated in the contract. Such a promise not to renegotiate is not credible since renegotiation can mitigate the dead-weight loss of liquidating insolvent borrowers. Once the initial contract may not consider the renegotiation procedure and renegotiation may occur, this paper investigates why a complete contract is not offered. It shows that the lender does not need to stipulate the renegotiation procedure on the initial contract because he is indifferent about committing or not to the terms of a contract. This indicates that a complete contract gives the lender the same expected return as an incomplete contract, in which the renegotiation process is determined after the occurrence of default.

KEY WORDS

incomplete contract, debt contract, renegotiation

JEL Classification

D82, C72

EST. ECON., SÃO PAULO, V. 35, N. 3, P. 461-480, JULHO-SETEMBRO 2005 


\section{INTRODUCTION}

This paper discusses the importance of renegotiation to mitigate the dead-weight loss of bankruptcy. It reveals that the lack of ability of a lender to write a complete contract does not affect his expected return and that the promise not to renegotiate the initial contract is not credible. This result contrasts with other models, such as the costly state verification of Townsend (1979) or Williamson (1987), that assumes commitment not to renegotiate the debt contract when default occurs. The same observation applies to the model of debt contract by Gale and Hellwig (1985).

The threat of bankruptcy on the costly state verification model induces complete separation between the successful and the unsuccessful borrower. The successful borrower pays back her debt and the unsuccessful borrower enters bankruptcy. The bankruptcy cost is a dead-weight loss of the arrangement. This could be avoided if the lender renegotiates the initial contract. Since this cost can be significantly high, this model demands an exogenous assumption about the lender's restriction not to renegotiate. In general, a contract determined without these assumptions is not renegotiation-proof. We investigate how a renegotiation proposal improves the agent's return by avoiding this dead-weight loss. We also show that the improvement is independent of the parties' ability to commit to a set of renegotiated outcomes.

In this paper, we consider an economy composed of many borrowers and one lender. The borrower has an investment project, but does not have capital to invest. The lender, that can be considered as a financial intermediary, provides capital to the borrower using a debt contract. The lender has the legal right to take over the project in case of default. Such a threat is not credible because there is a liquidation cost with bankruptcy. We then postulate that the lender would end up proposing renegotiation because this would reduce its costs by proposing renegotiation. However, the chance of profiting with renegotiation creates incentives to the solvent borrower to masquerade as insolvent.

To analyze the debt renegotiation process, the lender's problem is understood as the design of a mechanism that specifies the initial value of debt and the renegotiation terms. We investigate the best renegotiation plan that the lender can follow to minimize the liquidation cost without harming the borrower's incentive to pay. We are particularly interested in identifying a mechanism that is renegotiation-proof. This problem involves the design of a renegotiation procedure that determines how the initial contract is stipulated given the lender's willingness to renegotiate the proposal of a menu of offers. The lender faces the question of which clauses to incorporate in a contract. We use two approaches about the lender's possibility to write a contract. The first one anticipates the renegotiation stage by incorporating the renegotiation terms 
on the initial contract, while the second one does not allow the lender to include such terms.

We assume that renegotiation is followed with the proposal of a menu of offers. The lender has the bargain power and is able to unilaterally determine the renegotiation terms. The determination of the initial contract terms considers the ex-post bargain over the unknown project realization. The result of renegotiation is considered ex-ante when the initial contract is signed in order to determine the optimal debt value. A renegotiation procedure is then characterized according to the lender's ability to commit to the initial contract terms. Under the commitment approach, the lender includes the renegotiation terms on the initial contract and commits not to deviate from theses terms. The lender offers a complete contract in this case. It is possible, however, that this procedure may not be time consistent in absence of exogenous restrictions that would prevent the lender to include the renegotiation terms in the initial contract. Under the non-commitment approach, the renegotiation terms are not included in the initial contract. Instead they come out as a result of an ex-post bargain. In such situation, the lender offers an incomplete contract.

Under multiple offers with commitment the lender does not impose bankruptcy and randomizes over an offer that includes discount and another that includes a penalty. Default by the successful borrower can not be avoided under this approach. This renegotiation process is more efficient than one that does not admit renegotiation. Such an efficiency concept is used in the ex-post sense, in which improvements are made after the borrower learns his type. It signifies an improvement towards efficiency because the amount received from the successful borrower is higher than the amount received in case of bankruptcy. This result is the same under multiple offers without commitment.

With a menu of offers, there is more than one renegotiation outcome introducing a further source of uncertainty to the borrower and the lender does not renege to renegotiate. There is a shift on the source of uncertainty. Instead of being uncertain about the occurrence of renegotiation the borrower is now uncertain about the renegotiation outcome. It is also irrelevant if the menu is stated in the initial contract or if the lender chooses the best option after default in the renegotiation stage. That is, the lender is indifferent if he commits to a renegotiation procedure or if he chooses the procedure only in case of default. Both procedures are the same and give the same return. This shows the irrelevance of writing a complete debt contract.

Renegotiation of debt contract has been investigated in the literature under several different assumptions. Kahn and Huberman (1988b) investigate a renegotiation model where lenders have the same information as borrowers about the project realization 
but such information is not known to third parties. The authors assert that the terms of secured loan contracts are formulated in order to position parties optimally for subsequent renegotiation. The lender uses the foreclosure threat to induce total payment, but he will always renegotiate because he is much more inefficient managing the security than borrowers. On the renegotiation process, each part receives half of the difference between the social value of leaving the asset in the borrower's hand and the social value of the unrenegotiated loan.

Krasa and Villamil (1995) use a debt renegotiation game to show the optimality of a debt contract when the lender does not commit not to renegotiate. The necessity of renegotiation is a result of the dead-weight loss incurred with bankruptcy. Bester (1994) uses a stylized game of contract design and renegotiation where the entrepreneur has the option to default and the creditor can either exercise his right to foreclose on the debtor's assets or forgive a portion of the debt. The extent of the entrepreneur's liabilities in the optimal loan contract depends upon the creditor's commitment to impose bankruptcy if default occurs. In the absence of precommitment not to forgive, debt may efficiently be secured by additional outside assets. The idea is to reduce the deadweight loss from project liquidation by imposing a sufficiently high amount of collateral. The higher the degree of collateralization, the more inclined would be the creditor to believe that the project return is actually low when he observes default and less profitable is the option of taking over the project instead of forgiving a portion of the debt.

This paper can also be related to Kahn and Huberman (1988a) that illustrates the importance of some terms of a contract as a device to give power to one of the parties in case of renegotiation. In our situation, the bankruptcy threat gives the lender such a strategic advantage that he is indifferent to include more terms in the initial contract. In Kahn and Yavas (1994) this idea is used to investigate the importance of foreclosure on mortgage contracts.

Renegotiation has being used on the contract literature to investigate the fact that real world contractual transactions usually omit relevant terms to bind the agent behavior. Fudenberg and Tirole (1991) analyzed renegotiation in agency contracts, while Laffont and Tirole (1990) analyzed renegotiation in an environment of adverse selection. Dewatripont and Maskin (1990), Aghion, Dewatripont and Rey (1990, 1994) and Bolton (1992) investigated the properties of contracts robust to renegotiation.

This paper, however, is more interested on defining conditions when it is desirable to omit contractual terms. It is shown that the lender is not harmed by not considering every possible scenario from which renegotiation may evolve. Following this line, Aghion and Bolton (1992) shows how financial contracts depends on the possibility 
of randomizing control right. This paper also uses the approach of Hart \& Moore (1989) as the appropriated derivations of debt contract as the optimal contract to bind the borrower lender relationship in presence of renegotiation.

Following this introduction, the first section describes the renegotiation game. The second section analyzes the equilibrium in the commitment case and the third section analyzes the equilibrium of the non-commitment case. The fourth section analyzes the optimal renegotiation procedure, the fifth section analyzes the efficiency aspect of renegotiation and the last section concludes.

\section{THE RENEGOTIATION GAME}

The lender is a financial intermediary that deals with a representative borrower. $\mathrm{He}$ provides capital (I) to the borrower using the mechanism of a debt contract. ${ }^{1}$ The lender and the borrower are risk-neutral. The borrower has an investment project but does not have the liquid capital to invest; he possesses a wealth $\mathrm{w}$ in the form of an illiquid capital asset. The project realization, that is a function of the state $\theta$, where $\theta \in \Theta=\{\mathrm{L}, \mathrm{H}\}$, determines the borrower's type ex post $\mathrm{B}^{\theta}$. It will be used the expression $B^{L}$ to represent the low payment capacity borrower and the expression $B^{H}$ to represent the high payment capacity borrower. The production technology transforms one unit of capital in $\mathrm{y}_{\theta}$ units in next period, where $\mathrm{y}_{\mathrm{H}}>\mathrm{y}_{\mathrm{L}}$. Consider $\mathrm{q}$ as the probability that $\mathrm{y}_{\mathrm{H}}$ occurs.

In the contracting period, the lender offers a debt contract to the borrower. $\mathrm{C}_{1}$ states the face value of the debt $\mathrm{R}$, where $\mathrm{R}>\mathrm{I}$, and that the lender will foreclose the project if $\mathrm{R}$ is not paid. It is assumed that $\mathrm{R} \geq \mathrm{y}_{\mathrm{L}}$ and the lender can not recover $\mathrm{I}$ in case of project failure, that is, $\mathrm{I}>\mathrm{y}_{\mathrm{L}}$.

The realization of the project is private knowledge to the entrepreneur. The lender learns the project realization by imposing bankruptcy. The borrower pays $\mathrm{R}$ or defaults. $B^{L}$ always defaults, once it is assumed that her return $y_{L}$ is lower than the face value of debt, and $\mathrm{B}^{\mathrm{H}}$, giving a return being greater than the face value of debt, may choose between can paying or defaulting. The lender can impose bankruptcy or propose renegotiation in case of default. The bankruptcy procedure is exogenous. With bankruptcy, the debt value $\mathrm{R}$ is forgiven but the investment project would be seized by the lender. Bankruptcy is costly but credible. When the lender imposes

1 The relevant assumption that makes debt contract optimal is used, what indicates that considering debt contract is not a problem. KRASA \& VILLAMIL (1995) using a renegotiation game, what they call settlement game, similar to the one analyzed here are able to show that debt contract is optimal. The notion of debt contract secured by a collateral is not used. If we assume that the loss of taking over the collateral can be completely avoided, then we can show that the amount of collateral used is the maximum available. That is, the borrower's total wealth is used as collateral. 
bankruptcy, he incurs in a cost of $(1-\delta) \mathrm{y}_{\theta}$ to take over the project. ${ }^{2}$ When the lender takes over the project, he looses $\delta$ percent of the amount to be recovered. This occurs due to legal and transactional costs or due to the fact that banks lacks efficiency on managing the production process.

The bankruptcy loss is avoided by renegotiating. If the lender decides to renegotiate he would offer a new contract $\mathrm{C}_{2}$ that expresses the terms of the renegotiated value of the debt. Letting $\Re$ be the set of the new contracts that can be offered with renegotiation, define $\Delta(\Re)$ as the set of probability distributions over $\Re . \mathrm{C}_{2}$ is then a particular probability distribution of the renegotiated debt value picked from $\Delta(\Re) . \overline{\mathrm{R}}$ represents the new debt value and $\pi(\overline{\mathrm{R}})$ is the probability of offering $\overline{\mathrm{R}}$. In case of success, any excess available is captured by the new debt value.

We will consider two renegotiation regimes. In the first one the lender can commit when the first contract was signed not to alter its terms. Any rules for subsequent renegotiation of loan payment can be specified in the initial contract. In the second one the lender can not commit to any particular contract for the renegotiation stage.

It is assumed, as in Bester (1994), that the expected foreclosure value of the project exceeds the investment cost and the creditor's expected profit from making a loan can be made positive simply by allowing him to foreclose on the project in the event of default:

$$
\delta\left[q y_{H}+(1-q) y_{L}\right]>I
$$

The borrower chooses how often to default when she is solvent and the probability of accepting the lender's offer in the renegotiation stage. Her strategy set is $s_{\mathrm{B}}=\left(\sigma_{\mathrm{L}}, \sigma_{\mathrm{H}}, \mathrm{d}\right)$, where $\mathrm{B}^{\mathrm{H}}$ and $\mathrm{B}^{\mathrm{L}}$ accept the new contract with probability $\sigma_{\mathrm{H}}$ and $\sigma_{\mathrm{L}}$, respectively, and $d$ is the rate of default. The value of $\mathbf{d}$ is a strategy variable chosen by solvent borrowers. The lender's strategy is to offer $\mathrm{C}_{1}$ and to choose the frequency of renegotiation. Let $b$ be the probability that renegotiation will not be offered. The lender's strategy is expressed by $s_{L}=\left(R, C_{2}, b\right)$. The set of strategies is described as a function of the contract terms, where $s=\left(\mathrm{R} ; \sigma_{\mathrm{L}}, \sigma_{\mathrm{H}}, \mathrm{b}, \mathrm{d} ; \mathrm{C}_{2}\right)$.

Under both renegotiation procedures we consider renegotiation as the proposal of a menu of offers. The menu under commitment reflects a complete contract that has every single contingency described by the initial contract; while a menu under non-commitment reflects an incomplete contract that has its terms determined as a result of expost agreement. Next we will describe and characterize each of theses renegotiation procedures.

2 This is equivalent to the BESTER (1994) and KAHN \& HUBERMAN (1988) model as well as to the costly state verification approach. 


\section{RENEGOTIATION UNDER COMMITMENT}

Under commitment, the menu of renegotiation offers is not restricted to be the one that maximizes the lender's ex-post return in the renegotiation stage. The possibility to commit may increase the set of credible renegotiation offers. The lender can control the face value of debt by committing to a certain menu of renegotiation offers with a predetermined distribution. This means that it is necessary to consider every feasible menu in order to obtain the optimal commitment equilibrium.

A renegotiation procedure with multiple offers consists of a second contract $\mathrm{C}_{2}$ stating a menu of renegotiation offers. $\mathrm{C}_{2}$ determines the terms of the renegotiated contract and is expressed as a particular probability distribution of renegotiated debt value picked from $\Delta(\Re)$.

Figure 1 represents the renegotiation game:

\section{FIGURE 1}

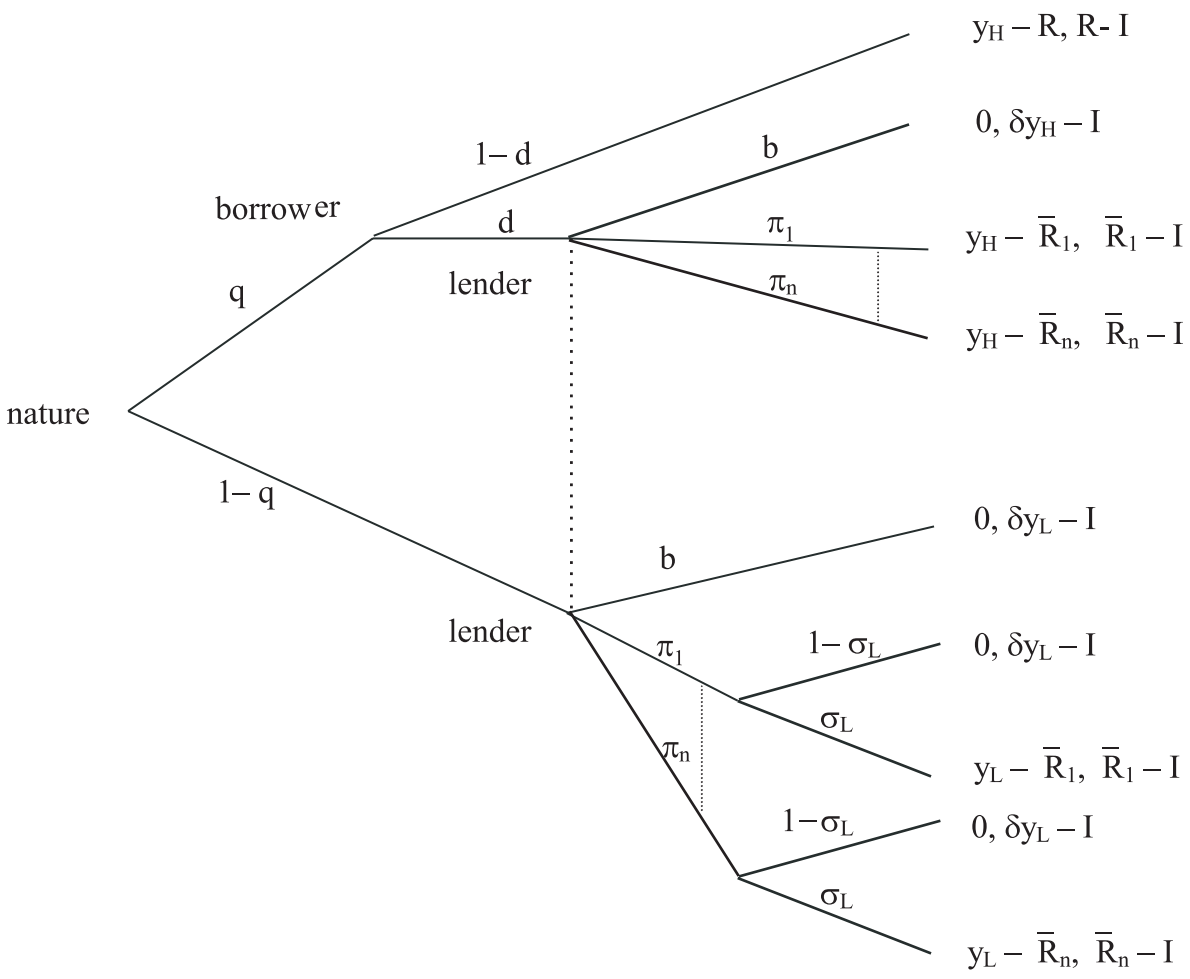

The timing of the renegotiation games is as follows. Nature determine the project return. The good type borrower decides about $\mathrm{d}$ if defaults or pays back 
$\mathrm{R}$. The bad type borrower defaults. In case of default the lenders decides about renegotiating or not and what to offer in case of renegotiation.

Considering the whole game, in the initial period, the lender offers a contract $\mathrm{C}_{1}$ with debt value $\mathrm{R}$ and $\mathrm{C}_{2}$ with the menu of renegotiation offers in case of default. The borrower has the option of paying back $\mathrm{R}$ or defaulting. If she defaults the lender will select a renegotiation offer from $\mathrm{C}_{2}$ or impose bankruptcy. The borrower then has the option of accepting the offer and paying the prescribed amount or defaulting. If she defaults she receives 0 and the lender receives a proportion $\delta$ of the project realization. The solvent borrower always accepts any offer and the insolvent borrower only accepts the offer of $y_{L}$.

The optimal menu maximizes the lender's expected return given the borrower's willingness to default and the individual rationality constraint. There are three cases to consider: the solvent borrower never defaults, the solvent borrower always defaults, the solvent borrower is indifferent between defaulting or not.

Let $\pi_{\mathrm{H}}$ be the probability that the offer equals $\mathrm{y}_{\mathrm{H}}$; let $\pi_{\mathrm{L}}$ be the probability that the offer equals $\mathrm{y}_{\mathrm{L}}$; let $\mathrm{b}$ be the probability of bankruptcy; let $\pi_{\mathrm{Hi}}$ be the probability that the offer is in the interval $\left(\mathrm{y}_{\mathrm{L}}, \mathrm{y}_{\mathrm{H}}\right)$ and let $\overline{\mathrm{R}}^{\mathrm{Hi}}$ be the expected value of the offer conditional on it being in this interval. Similarly, let $\pi_{\mathrm{Li}}$ be the probability that the offer is in the interval $\left(0, \mathrm{y}_{\mathrm{L}}\right)$ and let $\overline{\mathrm{R}}^{\mathrm{Li}}$ be the expected value of the offer conditional on it being in this interval. (offers above $\mathrm{y}_{\mathrm{H}}$ will not be used since they will always be rejected; offer which are rejected with certainty are dominated by $\mathrm{y}_{\mathrm{H}}$ ).

The lender's return can be expressed as:

$$
\begin{aligned}
\mathrm{LER}= & \mathrm{q}(1-\mathrm{d}) \mathrm{R}+\mathrm{qd}\left(\pi_{\mathrm{H}} \mathrm{y}_{\mathrm{H}}+\pi_{\mathrm{Hi}} \overline{\mathrm{R}}^{\mathrm{Hi}}+\pi_{\mathrm{Li}} \overline{\mathrm{R}}^{\mathrm{Li}}+\pi_{\mathrm{L}} \mathrm{y}_{\mathrm{L}}+\mathrm{b} \delta \mathrm{y}_{\mathrm{H}}\right) \\
& +(1-\mathrm{q})\left(\delta \mathrm{y}_{\mathrm{L}}+\pi_{\mathrm{L}}(1-\delta) \mathrm{y}_{\mathrm{L}}+\pi_{\mathrm{Li}}\left(\overline{\mathrm{R}}^{\mathrm{Li}}-\delta \mathrm{y}_{\mathrm{L}}\right)\right)-\mathrm{I}
\end{aligned}
$$

The optimal menu maximizes the lender's return subjected to an incentive compatibility condition on the borrower's decision to default. The lender should choose $\pi_{\mathrm{H}}, \pi_{\mathrm{Hi}}, \overline{\mathrm{R}}^{\mathrm{Hi}}, \pi_{\mathrm{Li}} \overline{\mathrm{R}}^{\mathrm{Li}}, \pi_{\mathrm{L}}$ and $\mathrm{b}$ in order to maximize his return.

In the following expression the left side is the borrower's surplus from defaulting and the right side is the borrower's surplus from not defaulting:

$$
\pi_{\mathrm{Hi}}\left(\mathrm{y}_{\mathrm{H}}-\overline{\mathrm{R}}^{\mathrm{Hi}}\right)+\pi_{\mathrm{Li}}\left(\mathrm{y}_{\mathrm{H}-} \overline{\mathrm{R}}^{\mathrm{Li}}\right)+\pi_{\mathrm{L}}\left(\mathrm{y}_{\mathrm{H}}-\overline{\mathrm{R}}^{\mathrm{L}}\right)=\left(\mathrm{y}_{\mathrm{H}}-\mathrm{R}\right)
$$


If the equality holds then the borrower is indifferent. Observe that if the left side is greater, then the borrower defaults with probability 1 ; while if it is lower, then borrower pays with probability one.

Finally the contract is limited by the borrower's individual rationality constraint of obtaining a certain return rate $\mathbf{r}$ by not pursuing the investment project and buying a safe asset or working on anything else that pays him such value. For this restriction be satisfied, we assume indifference to the borrower's choice by representing the following equality:

$$
\begin{aligned}
& \mathrm{r}=\mathrm{q}(\mathrm{l}-\mathrm{d})\left(\mathrm{y}_{\mathrm{H}}-\mathrm{R}\right)+\mathrm{qd}\left(\pi_{\mathrm{Hi}}\left(\mathrm{y}_{\mathrm{H}}-\overline{\mathrm{R}}^{\mathrm{Hi}}\right)+\pi_{\mathrm{L}}\left(\mathrm{y}_{\mathrm{H}}-\mathrm{y}_{\mathrm{L}}\right)+\pi_{\mathrm{Li}}\left(\mathrm{y}_{\mathrm{H}}-\overline{\mathrm{R}}^{\mathrm{Li}}\right)\right) \\
& +(1-q)\left(\pi_{\mathrm{Li}}\left(\mathrm{y}_{\mathrm{L}}-\overline{\mathrm{R}}^{\mathrm{Li}}\right)\right)
\end{aligned}
$$

In this equilibrium the lender offers a contract with face value $\mathrm{R}$ and the menu $\left\{\mathrm{y}_{\mathrm{H}}, \mathrm{y}_{\mathrm{L}}\right\}$ in case of renegotiation. Even though the lender can commit to any specific renegotiation offer or to any menu, there is a unique optimal menu. Assuming $\mathbf{R}_{\mathbf{M}}$ to represent the optimal face value of debt and $d_{M}$ to represent the borrower decision to default when there is a menu offer, proposition 1 states the equilibrium.

Proposition 1: The optimal menu is the offer of $y_{H}$ with probability $\pi_{H}{ }^{*}=\frac{R_{M}-y_{L}}{y_{H}-y_{L}}$ and $\mathrm{y}_{\mathrm{L}}$ with probability $\pi_{\mathrm{L}}{ }^{*}=\frac{\mathrm{y}_{\mathrm{H}}-\mathrm{R}_{\mathrm{M}}}{\mathrm{y}_{\mathrm{H}}-\mathrm{y}_{\mathrm{L}}}$. The borrower always defaults when insolvent and defaults with probability $\mathrm{d}_{\mathrm{M}}=\mathrm{d}_{\mathrm{M}}{ }^{*}$ when solvent, where $\mathrm{d}_{\mathrm{M}}{ }^{*}=\frac{(1-\mathrm{q})(1-\delta) \mathrm{y}_{\mathrm{L}}}{\mathrm{q}\left(\mathrm{y}_{\mathrm{H}}-\mathrm{y}_{\mathrm{L}}\right)}$. The solvent borrower always accepts any offer and the insolvent only accepts the offer lower or equal to $\mathrm{y}_{\mathrm{L}}$. Bankruptcy only occurs when an offer is not accepted.

The lender's expected return is $\operatorname{LER}_{M}=q\left(1-d_{M}\right) R_{M}+q_{M} y_{H}+(1-q) \delta y_{L}-I$, and the borrower receives her reservation income r. From the borrower's individual rationality constraint $R_{M}$ is determined as $y_{H}-r / q$.

We proceed with the proof by analyzing each of the three forms of 2 as a separated problem. The strategy to solve the problem is to maximize the lender's expected return assuming one specific case. This procedure is repeated for the three conditions. The optimal menu maximizes the overall lender's expected return that has satisfied the borrower's reaction function.

Proof: see appendix 
In other words, the optimal contract in the commitment case has a menu with just two renegotiation offers. Next section investigates the renegotiation when the lender does not commit.

\section{RENEGOTIATION UNDER NON COMMITMENT}

The commitment case assumes that the initial contract states every renegotiated term and that the lender does not deviate from these terms when renegotiation is in fact proposed. This procedure may not be time consistent in the sense that it may not be optimal to the lender to propose the pre-committed value of $\bar{R}$ or the pre-committed menu.

In this section we analyze if the impossibility of writing a complete contract alters the lender's return by studying the renegotiation procedure under non-commitment. Such procedure reflects the situation when the lender is unable to write every contingency in the initial contract.

Under non-commitment the lender offers a contract with debt value $\mathrm{R}$ and is free to make any renegotiation offer in case of default. The borrower has the option to pay back $\mathrm{R}$ or to default. If she defaults the lender will randomly select a renegotiation offer or impose bankruptcy. The borrower then has the option to accept the offer paying the prescribed amount or to default. If she defaults she receives 0 and the lender receives the realization times $\delta$. The solvent borrower always accepts any offer and the insolvent only accepts an offer equal or lower than $y_{L}$.

The rationale of the non-commitment case is that in the occasion that the lender tends to offer $\overline{\mathrm{R}}>\mathrm{y}_{\mathrm{L}}$ the best that he can do is to offer $\overline{\mathrm{R}}=\mathrm{y}_{\mathrm{H}}$. Since at the bad state the borrower is not able to pay any $\overline{\mathrm{R}}>\mathrm{y}_{\mathrm{L}}$, only the borrower at good state can pay this $\overline{\mathrm{R}}$, this implies that the lender can pose $\overline{\mathrm{R}}$ slightly lower than $\mathrm{y}_{\mathrm{H}}$ and extract all the surplus from $\mathrm{B}^{\mathrm{H}}$. Such an offer does not allow the lender to share the benefit of renegotiation with the borrower, it works like an incentive device to obligate $\mathrm{B}^{\mathrm{H}}$ not to default. The offer of $\bar{R}=y_{H}$, in fact slightly smaller than $y_{H}$ to make $\sigma_{H}=1$, should not always be done because there is a probability $q$ that the borrower is not able to pay $\mathrm{R}$. So, $\overline{\mathrm{R}}=\mathrm{y}_{\mathrm{L}}$ could be proposed with some frequency to avoid the dead-weight loss, (1-

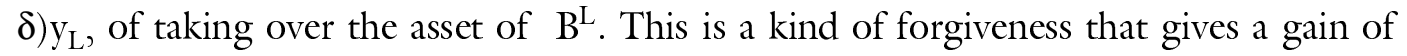
$\left(\mathrm{y}_{\mathrm{H}}-\mathrm{y}_{\mathrm{L}}\right)$ to $\mathrm{B}^{\mathrm{H}}$. This rent is the benefit that the borrower gets with the chance that renegotiation would be proposed. Proposition 2 shows the multiple offer equilibrium under non-commitment. 
Proposition 2: Under the multiple offer set up there is a unique equilibrium when the lender can not commit. Such an equilibrium is the same equilibrium of the commitment case with menu.

Proof: see appendix

The menu under non-commitment is also time consistent because after the borrower has defaulted with probability $\mathrm{d}_{\mathrm{M}}$, the lender keeps the same expected return by setting $\pi_{\mathrm{H}}=0$ or $\pi_{\mathrm{L}}=0$, or both. It is not, however, with certainty that this equilibrium is feasible. The constraint about $\mathrm{R}>\mathrm{I}$ demands that $\mathrm{r}<\mathrm{q}\left(\mathrm{y}_{\mathrm{H}-} \mathrm{y}_{\mathrm{L}}\right)$.

This equilibrium is characterized by the fact that the lender does not renege to renegotiate, allowing him to make a simultaneous offer of $\overline{\mathrm{R}}=\mathrm{y}_{\mathrm{H}}$ with probability $\pi_{\mathrm{H}}{ }^{*}$ and $\overline{\mathrm{R}}=\mathrm{y}_{\mathrm{L}}$ with probability $\pi_{\mathrm{L}}{ }^{*}$.

Consider some remarks before explaining the equivalence of the two equilibria with further details, what is deferred to the next section. Similar renegotiation game was used by Krasa and Villamil (1995) to show the optimality of debt contract under the possibility of renegotiation. As it is analyzed here, the necessity of renegotiation is a result of the dead-weight loss incurred with bankruptcy. They use an investment project with a finite number of possible realization and their renegotiation stage model consist of 4 steps. The borrower first decides what proportion of the debt will be paid, the lender randomizes over the offer of many renegotiation proposals, the borrower accepts or rejects such an offer and then the lender decides to enforce in court or not. This last stage is shown to be deterministic, that is, there is a threshold value that determine when enforcement must occur. Enforcement is deterministically executed but the offer of new contract terms is stochastic. ${ }^{3}$

\section{THE OPTIMAL RENEGOTIATION PROCEDURE}

The structure of the renegotiation procedure under commitment to a menu is basically the same when there is no commitment to such a menu. The difference between the two approaches is that the lender has a unique choice of menu under non-commitment while he faces many possibilities under commitment. However, there is only one credi-

3 The non-commitment case is similar approach to KRASA \& VILLAMIL (1995) with the exception of the specific objective; while one is trying to prove the optimality of debt contract, the other is trying to characterize the best strategy that the lender should follow to propose a debt contract and renegotiate its terms. The authors' approach to the renegotiation game implicitly allows the lender to refuse to renegotiate as he offers no discount over the original value of debt. Our model assumes a priori that bankruptcy is imposed when an offer is not accepted, this result is endogenously derived by KRASA \& VILLAMIL (1995) and consists of the fundamental proof of debt contract optimality. 
ble menu under commitment and this menu coincides with the credible menu under non-commitment.

As $\left\{\mathrm{y}_{\mathrm{L}}, \mathrm{y}_{\mathrm{H}}\right\}$ is the optimal menu that the lender can offer and as the lender is not free to choose $\left(\pi_{\mathrm{L}}, \pi_{\mathrm{H}}\right)$, there is no difference between an outcome obtained under commitment or non-commitment. In both equilibria it is the case that $\mathrm{y}_{\mathrm{H}}$ is offered with probability $\pi_{\mathrm{H}}{ }^{*}=\frac{\mathrm{R}_{\mathrm{M}}-\mathrm{y}_{\mathrm{L}}}{\mathrm{y}_{\mathrm{H}}-\mathrm{y}_{\mathrm{L}}}, \mathrm{y}_{\mathrm{L}}$ is offered with probability $\pi_{\mathrm{L}}{ }^{*}=\frac{\mathrm{y}_{\mathrm{H}}-\mathrm{R}_{\mathrm{M}}}{\mathrm{y}_{\mathrm{H}}-\mathrm{y}_{\mathrm{L}}}$ and the borrower always defaults when insolvent and defaults with probability $d_{M}{ }^{*}=\frac{(1-q)(1-\delta) y_{L}}{q\left(y_{H}-y_{L}\right)}$ when solvent.

The idea behind the equivalence of both equilibria is that the equilibrium in mixed strategy constrains the borrower's choice of $\overline{\mathrm{R}}$ to a specific randomization rule. This also constrains the possibility of committing to any randomization over the menu. The lender is not free to choose $\left(\pi_{\mathrm{L}}, \pi_{\mathrm{H}}\right)$ because $\left(\pi_{\mathrm{L}}, \pi_{\mathrm{H}}\right)$ must be such that the borrower is indifferent between defaulting or not. Committing to other randomization does not satisfy the borrower's incentive condition, what means that the commitment and noncommitment approach should coincide. It is the incentive constraint that induces the same result.

The two renegotiation procedures under commitment require bankruptcy as a necessary threat to avoid default. Commitment to an offer implies that the borrower knows the renegotiation outcome, while the bankruptcy threat makes her uncertain when such an outcome will be reached. This uncertainty constraints the borrower's willingness to default. A higher frequency of bankruptcy induces a lower frequency of default but also induces a higher loss due to default. Without commitment to an offer, there is more than one renegotiation outcome introducing a further source of uncertainty to the borrower. There is, however, renegotiation for sure and the device that induces the borrower's best behavior is translated to the uncertainty about which renegotiation will be offered. Contrary to Gale andHelliwg (1989), there is no improvement when the agents coordinate toward a deterministic renegotiation outcome. The threat of a renegotiation offer with the value of the project good realization ensures an unconditional improvement on the lender's return. This occurs independently of the rate of default.

The uncertainty about bankruptcy is essential as an incentive device under commitment. If the lender could commit not to impose bankruptcy and still avoid default by the successful borrower he could appropriate the totality of the renegotiation gains. The problem is that such a process is not possible without the help of a different mechanism that avoids default and allows renegotiation. A way to precommit to renegotiate 
without appealing to the bankruptcy threat is through the use of a verification technology. Such technology gives the lender a signal about the project realization before the renegotiation stage.

\section{ADVANTAGE OF RENEGOTIATION}

The advantage of a contract with renegotiation over one where renegotiation is not allowed is expressed by Proposition 3:

Proposition 3: Inducing renegotiation in contract is valuable.

The following arguments demonstrate this proposition. Under the non-renegotiation scheme the lender has to take over the borrower's asset whenever default occurs, i.e., $b=1$ if the payment is $y_{L}, b=0$ when the payment is $R$. When renegotiation leads to an improvement in the agent's expected return, it should be expected that the lender tries to benefit from this opportunity. On the occasion of commitment not to renegotiate, the LER is equal to one of the Non-default_Equilibrium case with renegotiation; i.e., $\mathrm{LER}=\mathrm{qR}+(\mathrm{l}-\mathrm{q}) \delta \mathrm{y}_{\mathrm{L}}-\mathrm{I}$.

The multiple proposal renegotiation process is more efficient than the case where there is precommitment not to renegotiate at all. The face value of debt is the same for the procedure under commitment and under non-commitment. The advantage of renegotiation occurs because the menu allows the lender to reduce the cost of bankrupting the insolvent borrower and, at the same time, allows him to appropriate part of the solvent borrower surplus. This implies that, independently of the renegotiation procedure, a lending-borrowing process where the lender commits ex-ante not to renegotiate is a non credible promise.

\section{CONCLUSION}

We analyze a renegotiation game in which, contrary to Bester (1994), the new contract proposed is determined in accordance to the specific renegotiation procedure. Under commitment the lender determines the terms of the contract proposed in the renegotiation as part of their strategic decision about renegotiating. He faces the problem of bargaining over an unknown amount in order to determine the specific terms and must decide how much of the renegotiation gain to share with the borrower. Under non-commitment, the new contract maximizes the lender's return in the renegotiation stage. We also assume that the lender has some discretionary power to stipulate the face value of debt. 
As expected, a promise not to renegotiate the original contract is not credible. The reason for the renegotiation is the possibility of minimization of the dead-weight loss with inefficient liquidation. One drawback of renegotiation is that some degree of default from the successful borrower must be admitted, characterizing a partially pooling equilibrium in debt renegotiation. Although the lender has all the bargaining power to determine the terms and the decision to offer a new contract, he can not avoid the transference of rent to the solvent borrower. Such a borrower gets informational rent from the renegotiation opportunity.

Under commitment, renegotiation is pursued with the determination of a menu of offers in the initial contract; while under non-commitment, renegotiation is pursued with a randomization over many offers that are not stipulated on the initial contract. However, the optimal menu is the same for both processes. The lender thus is indifferent to commit or not to a procedure that stipulates the renegotiation terms as part of the initial contract.

This shows that the impossibility of writing a complete debt contract does not harm the lender's return. This explain the occurrence of a debt contract without the explicit renegotiation procedure. Only the right to seizure and the conditions of this process are usually stipulated in the contract. The opportunity to renegotiate is not customarily part of a contract. As this paper argues, this is not necessary because the lender can mimic the terms of the optimal complete contract at the renegotiation stage.

APPENDIX

\section{A) Proof of Proposition 1}

First step: Consider that the solvent borrower is indifferent between default and payment

This step covers the case that:

$$
\pi_{\mathrm{Hi}}\left(\mathrm{y}_{\mathrm{H}}-\overline{\mathrm{R}}^{\mathrm{Hi}}\right)+\pi_{\mathrm{Li}}\left(\mathrm{y}_{\mathrm{H}}-\overline{\mathrm{R}}^{\mathrm{Li}}\right)+\pi_{\mathrm{L}}\left(\mathrm{y}_{\mathrm{H}}-\mathrm{y}_{\mathrm{L}}\right)=\left(\mathrm{y}_{\mathrm{H}-} \mathrm{R}\right)
$$

Considering the borrower's reaction 2':

$$
\pi_{\mathrm{L}}=\frac{\mathrm{y}_{\mathrm{H}}-\mathrm{R}+\pi_{\mathrm{Hi}}\left(\overline{\mathrm{R}}^{\mathrm{Hi}}-\mathrm{y}_{\mathrm{H}}\right)+\pi_{\mathrm{Li}}\left(\overline{\mathrm{R}}^{\mathrm{Li}}-\mathrm{y}_{\mathrm{H}}\right)}{\mathrm{y}_{\mathrm{H}}-\mathrm{y}_{\mathrm{L}}}
$$


and by the fact that $\pi_{\mathrm{H}}=1-\pi_{\mathrm{Hi}}-\pi_{\mathrm{L}}-\pi_{\mathrm{Li}}-\mathrm{b}$, we have by substituting 4 in $\mathrm{l}$ :

$$
\begin{aligned}
\mathrm{LER}_{\pi} & =\mathrm{q}\left(1-\frac{(1-\mathrm{q})(1-\delta) \mathrm{y}_{\mathrm{L}}}{\mathrm{q}\left(\mathrm{y}_{\mathrm{H}}-\mathrm{y}_{\mathrm{L}}\right)}\right) \mathrm{R}+(\mathrm{l}-\mathrm{q}) \delta \mathrm{y}_{\mathrm{L}}+(\mathrm{l}-\mathrm{q}) \pi_{\mathrm{Li}}\left(\overline{\mathrm{R}}^{\mathrm{Li}}-\delta \mathrm{y}_{\mathrm{L}}\right)-\mathrm{qdb}(\mathrm{l}-\delta) \mathrm{y}_{\mathrm{H}} \\
& +(\mathrm{l}-\mathrm{q})(\mathrm{l}-\delta) \mathrm{y}_{\mathrm{L}} \frac{\mathrm{y}_{\mathrm{H}}+\pi_{\mathrm{Hi}}\left(\overline{\mathrm{R}}^{\mathrm{Hi}}-\mathrm{y}_{\mathrm{H}}\right)+\pi_{\mathrm{Li}}\left(\overline{\mathrm{R}}^{\mathrm{Li}}-\mathrm{y}_{\mathrm{H}}\right)}{\mathrm{y}_{\mathrm{H}}-\mathrm{y}_{\mathrm{L}}}-\mathrm{I}
\end{aligned}
$$

This expression can be simplified:

$$
\begin{aligned}
\operatorname{LER}_{\pi} & =\mathrm{q}\left(1-\frac{(1-\mathrm{q})(1-\delta) \mathrm{y}_{\mathrm{L}}}{\mathrm{q}\left(\mathrm{y}_{\mathrm{H}}-\mathrm{y}_{\mathrm{L}}\right)}\right) \mathrm{R}+(1-\mathrm{q}) \delta \mathrm{y}_{\mathrm{L}}+(1-\mathrm{q}) \frac{\left(\mathrm{y}_{\mathrm{H}}-\delta \mathrm{y}_{\mathrm{L}}\right)}{\left(\mathrm{y}_{\mathrm{H}}-\mathrm{y}_{\mathrm{L}}\right)} \pi \mathrm{L}_{\mathrm{i}}\left(\overline{\mathrm{R}}^{\mathrm{Li}-} \mathrm{y}_{\mathrm{H}}\right) \\
& -\mathrm{qdb}(1-\delta) \mathrm{y}_{\mathrm{H}}+(1-\mathrm{q})(1-\delta) \mathrm{y}_{\mathrm{L}} \frac{\mathrm{y}_{\mathrm{H}}+\pi_{\mathrm{Hi}}\left(\overline{\mathrm{R}}^{\mathrm{Hi}}-\mathrm{y}_{\mathrm{H}}\right)}{\mathrm{y}_{\mathrm{H}}-\mathrm{y}_{\mathrm{L}}}-\mathrm{I}
\end{aligned}
$$

From the borrower's reaction function 2' this constraint is transformed to:

$$
\mathrm{r}=\mathrm{q}\left(\mathrm{y}_{\mathrm{H}}-\mathrm{R}\right)+(\mathrm{l}-\mathrm{q}) \pi_{\mathrm{Li}}\left(\mathrm{y}_{\mathrm{L}}-\overline{\mathrm{R}}^{\mathrm{Li}}\right)
$$

and the face value of debt is:

$$
\mathrm{R}=\mathrm{y}_{\mathrm{H}}-\left(\mathrm{r}+(\mathrm{l}-\mathrm{q}) \pi_{\mathrm{Li}}\left(\mathrm{y}_{\mathrm{L}}-\overline{\mathrm{R}}^{\mathrm{Li}}\right)\right) / \mathrm{q}
$$

Substituting this value in the lender's return 5':

$$
\begin{aligned}
& \operatorname{LER}_{\pi}=\mathrm{q}\left(1-\frac{(1-\mathrm{q})(1-\delta) \mathrm{y}_{\mathrm{L}}}{\mathrm{q}\left(\mathrm{y}_{\mathrm{H}}-\mathrm{y}_{\mathrm{L}}\right)}\right)\left(\mathrm{y}_{\mathrm{H}}-\mathrm{r} / \mathrm{q}\right)+(1-\mathrm{q}) \delta \mathrm{y}_{\mathrm{L}}-\mathrm{qdb}(1-\delta) \mathrm{y}_{\mathrm{H}} \\
& +\frac{(1-q)}{q\left(y_{H}-y_{L}\right)} \pi L_{i}\left(\left(\bar{R}^{L i}-y_{L}\right)(1-\delta) y_{L}-q\left(y_{H}-y_{L}\right)\left(y_{H}-\delta y_{L}\right)\right. \\
& +(1-q)(1-\delta) y_{L} \frac{y_{H}+\pi_{H i}\left(\overline{\mathrm{R}}^{\mathrm{Hi}}-\mathrm{y}_{\mathrm{H}}\right)}{\mathrm{y}_{\mathrm{H}}-\mathrm{y}_{\mathrm{L}}}-\mathrm{I}
\end{aligned}
$$

As $\quad \overline{\mathrm{R}}^{\mathrm{Li}}<\mathrm{y}_{\mathrm{L}}$ and $\overline{\mathrm{R}}^{\mathrm{Hi}}<\mathrm{y}_{\mathrm{H}}$, this expression is maximized by setting $\mathrm{b}=0, \pi_{\mathrm{Hi}}=0$ and $\pi_{\mathrm{Li}}=0$. Thus the menu $\left\{\mathrm{y}_{\mathrm{H}}, \mathrm{y}_{\mathrm{L}}\right\}$ is optimal for any $\mathrm{d} \in(0,1)$. In this case $5 "$ simplifies to:

$$
\operatorname{LER}_{\pi}=q\left(1-d_{M}^{*}\right) R_{M}+(1-q) \delta y_{L}+q_{M}{ }^{*} y_{H}-I
$$

Note that the important fact is that the randomization offer must be fixed to allow the borrower to be indifferent between defaulting or not. The probabilities $\pi_{\mathrm{H}}$ and $\pi_{\mathrm{L}}$ are determined to satisfy the indifference condition $2^{\prime} \pi_{\mathrm{H}} \mathrm{y}_{\mathrm{H}}+\pi_{\mathrm{L}} \mathrm{y}_{\mathrm{L}}=\mathrm{R}$. The borrower's default rate is such that the lender is indifferent between each of the menu offers, that is, 


$$
\mathrm{qd}_{\mathrm{M}} \mathrm{y}_{\mathrm{H}}+(\mathrm{l}-\mathrm{q}) \delta \mathrm{y}_{\mathrm{L}}=\mathrm{qd}_{\mathrm{M}} \mathrm{y}_{\mathrm{L}}+(\mathrm{l}-\mathrm{q}) \mathrm{y}_{\mathrm{L}}
$$

Second step: Consider that the solvent borrower never defaults

This step covers the case that:

$$
\pi_{\mathrm{Hi}}\left(\mathrm{y}_{\mathrm{H}}-\overline{\mathrm{R}}^{\mathrm{Hi}}\right)+\pi_{\mathrm{Li}}\left(\mathrm{y}_{\mathrm{H}}-\overline{\mathrm{R}}^{\mathrm{Li}}\right)+\pi_{\mathrm{L}}\left(\mathrm{y}_{\mathrm{H}}-\mathrm{y}_{\mathrm{L}}\right) \leq\left(\mathrm{y}_{\mathrm{H}}-\mathrm{R}\right)
$$

When $\mathrm{d}=0$ the lender's return simplifies to:

$$
\mathrm{LER}=\mathrm{qR}+(\mathrm{l}-\mathrm{q})\left(\delta \mathrm{y}_{\mathrm{L}}+\pi_{\mathrm{Li}}\left(\overline{\mathrm{R}}^{\mathrm{Li}}-\delta \mathrm{y}_{\mathrm{L}}\right)+\pi_{\mathrm{L}}\left(\mathrm{y}_{\mathrm{L}}-\delta \mathrm{y}_{\mathrm{L}}\right)\right)-\mathrm{I}
$$

The borrower's individual rationality constraint 3 with $\mathrm{d}=0$ is the same as 3 '. Combining 7 and 3 ' we have:

$$
\mathrm{LER}=\mathrm{qy}_{\mathrm{H}}-\mathrm{r}+(\mathrm{l}-\mathrm{q}) \delta \mathrm{y}_{\mathrm{L}}+(\mathrm{l}-\mathrm{q})\left(\pi_{\mathrm{Li}}\left(\mathrm{y}_{\mathrm{L}}-\delta \mathrm{y}_{\mathrm{L}}\right)+\pi_{\mathrm{L}}\left(\mathrm{y}_{\mathrm{L}}-\delta \mathrm{y}_{\mathrm{L}}\right)\right)-\mathrm{I}
$$

Our goal is thus to maximize 8 subject to $2 "$. This is maximized when $\pi_{\mathrm{Hi}}=0, \pi_{\mathrm{Li}}=0$, $\pi_{L}=\frac{y_{H}-R_{M}}{y_{H}-y_{L}}$ and $\pi_{H}=\frac{R_{M}-y_{L}}{y_{H}-y_{L}}$. Thus in the best alternative when the borrower never defaults the borrower is indifferent between defaulting and not, so the best possibility in this region has already been induced in the first step.

Third step: Consider that the solvent borrower always defaults

This step covers the case that:

$$
\pi_{\mathrm{Hi}}\left(\mathrm{y}_{\mathrm{H}}-\overline{\mathrm{R}}^{\mathrm{Hi}}\right)+\pi_{\mathrm{Li}}\left(\mathrm{y}_{\mathrm{H}}-\overline{\mathrm{R}}^{\mathrm{Li}}\right)+\pi_{\mathrm{L}}\left(\mathrm{y}_{\mathrm{H}^{-}} \mathrm{y}_{\mathrm{L}}\right) \geq\left(\mathrm{y}_{\mathrm{H}}-\mathrm{R}\right)
$$

For $\mathrm{d}=1$ the lender's return is:

$$
\begin{aligned}
\mathrm{LER}= & \mathrm{q}\left(\pi_{\mathrm{H}} \mathrm{y}_{\mathrm{H}}+\pi_{\mathrm{Hi}} \overline{\mathrm{R}}^{\mathrm{Hi}}+\pi_{\mathrm{L}} \mathrm{y}_{\mathrm{L}}+\pi_{\mathrm{Li}} \overline{\mathrm{R}}^{\mathrm{Li}}+\mathrm{b} \delta \mathrm{y}_{\mathrm{H}}\right)+(\mathrm{l}-\mathrm{q}) \delta \mathrm{y}_{\mathrm{L}} \\
& +(\mathrm{l}-\mathrm{q})\left(\pi_{\mathrm{L}}(1-\delta) \mathrm{y}_{\mathrm{L}}+\pi_{\mathrm{Li}}\left(\overline{\mathrm{R}}^{\mathrm{Li}}-\delta \mathrm{y}_{\mathrm{L}}\right)\right)-\mathrm{I}
\end{aligned}
$$

This expression is rewritten as:

$$
\begin{aligned}
\mathrm{LER}= & \pi_{\mathrm{H}}\left(\mathrm{qy}_{\mathrm{H}}+(\mathrm{l}-\mathrm{q}) \delta \mathrm{y}_{\mathrm{L}}\right)+\pi_{\mathrm{Hi}}\left(\mathrm{q} \overline{\mathrm{R}}^{\mathrm{Hi}}+(\mathrm{l}-\mathrm{q}) \delta \mathrm{y}_{\mathrm{L}}\right)+\mathrm{b}\left(\mathrm{q} \delta \mathrm{y}_{\mathrm{H}}+(\mathrm{l}-\mathrm{q}) \delta \mathrm{y}_{\mathrm{L}}\right) \\
& +\pi_{\mathrm{L}} \mathrm{y}_{\mathrm{L}}+\pi_{\mathrm{Li}} \overline{\mathrm{R}}^{\mathrm{Li}}-\mathrm{I}
\end{aligned}
$$


The highest $\pi_{\mathrm{H}}$ must be chosen in order to maximize the lender's return. This implies $\pi_{\mathrm{Hi}}=0$ and that $\pi_{\mathrm{L}}$ must be the lowest possible. From the borrower's reaction function we have that $\pi_{L}=\frac{y_{H}-R_{M}}{y_{H}-y_{L}}$. Thus in the best alternative when the borrower always defaults the borrower is indifferent between defaulting and not, so the best possibility in this region has already been induced in the first step. The individual rationality constraint is satisfied with $R=R_{M}$.

\section{B) Proof of Proposition 2}

To derive the multiple offer equilibrium under non-commitment we first derive the credible renegotiation offer. Then, we show that the equilibrium must be in completely mixed strategy.

First step: derivation of the credible renegotiation offer.

We show that $\left\{\mathrm{y}_{\mathrm{H}}, \mathrm{y}_{\mathrm{L}}\right\}$ is the menu that maximize the lender's expected return given any borrower's action.

When faced with a renegotiation offer a borrower has a simple strategy. A solvent borrower accepts any offer lower than $y_{H}$, rejects any offer greater than $y_{H}$, and is indifferent with an offer equal to $y_{H}$. An insolvent borrower accepts any offer lower than $y_{L}$, rejects any offer greater than $y_{L}$, and is indifferent with an offer equal to $y_{L}$. For the time being, assume that the borrower accepts when indifferent. (Later we will show that there is no equilibrium when the borrower randomizes over accepting or not when she is indifferent) Clearly the lender will not offer $\bar{R}>y_{H}$, since such an offer will always be rejected and it is dominated by $\overline{\mathrm{R}}=\mathrm{y}_{\mathrm{H}}$. For $\overline{\mathrm{R}} \leq \mathrm{y}_{\mathrm{H}}$, the lender's expected outcome of an offer is:

$$
\mathrm{F}(\overline{\mathrm{R}}, \mathrm{d})=\mu \overline{\mathrm{R}}+\mu\left(\delta \mathrm{y}_{\mathrm{L}}+\left(\overline{\mathrm{R}}-\delta \mathrm{y}_{\mathrm{L}}\right) \sigma_{\mathrm{L}}\right)
$$

where $\sigma_{\mathrm{L}}=0$ if $\overline{\mathrm{R}}>\mathrm{y}_{\mathrm{L}}, \sigma_{\mathrm{L}}=1$ otherwise; and $\mu$ is the lender's belief that the borrower

is solvent, $\mu=\frac{q d}{q d+(1-q)}$. Bankruptcy is equivalent to the offer $\bar{R}=\delta y_{H}$ and to the seizure of borrower's outcome. It is, however, strictly dominated by $\bar{R}=y_{H}$.

Given the lender's strategy, as a best response result, and the probability of default by each type of borrower, the offers that are not dominated are $y_{H}$ and $y_{L}$. Any offer between $\mathrm{y}_{\mathrm{L}}$ and $\mathrm{y}_{\mathrm{H}}$ is accepted with the same probability thus the lender may as well of- 
fer $y_{H}$. Any offer less than $y_{L}$ is always accepted, therefore the lender may as well offer $\mathrm{y}_{\mathrm{L}}$. Which of these two is best depends on the relative likelihood of the borrower being one of these two types:

$$
\begin{aligned}
& \overline{\mathrm{R}}=\mathrm{y}_{\mathrm{L}} \text { if } 0 \leq \mathrm{d} \leq \mathrm{d}_{\mathrm{M}} \\
& \overline{\mathrm{R}}=\mathrm{y}_{\mathrm{H}} \text { if } \mathrm{l} \geq \mathrm{d} \geq \mathrm{d}_{\mathrm{M}} .
\end{aligned}
$$

In other words, $\mathrm{y}_{\mathrm{H}}$ is the best offer if it is likely that the lender is of type $\mathrm{H}, \mathrm{y}_{\mathrm{L}}$ is the best offer if it is likely that the lender is of type $\mathrm{L}$. If $\mathrm{d}=\mathrm{d}_{\mathrm{M}}$, the lenders is indifferent between the two offers: $F\left(y_{L}, d_{M}\right)=F\left(y_{H}, d_{M}\right)$.

So far we have treated the default decision as exogenous, we next consider which frequency of default can occur in equilibrium. We will show that $\mathrm{d}_{\mathrm{M}}$ is the only possibility.

Second step: show that the equilibrium is in mixed strategy.

Consider any possible offer $\overline{\mathrm{R}}^{\mathrm{i}} \in\left[0, \mathrm{y}_{\mathrm{H}}\right]$ and let $\pi_{\mathrm{i}}$ be the probability of such an offer. The solvent borrower decides to pay if the expected renegotiation gain $\sum \pi_{i}\left(y_{H}-\bar{R}^{i}\right)$ is lower than the outcome with payment $\mathrm{y}_{\mathrm{H}}-\mathrm{R}$. By the analysis above, we can restrict the lender's renegotiation proposal to $\mathrm{y}_{\mathrm{H}}$ with probability $\pi_{\mathrm{H}}$ and $\mathrm{y}_{\mathrm{L}}$ with probability $\pi_{\mathrm{L}}$. Given the borrower's best response consider that:

a) $\left(\mathrm{y}_{\mathrm{H}}-\mathrm{y}_{\mathrm{H}}\right) \pi_{\mathrm{H}}+\left(\mathrm{y}_{\mathrm{H}}-\mathrm{y}_{\mathrm{L}}\right) \pi_{\mathrm{L}}>\mathrm{y}_{\mathrm{H}}-\mathrm{R}$.

This implies that $d=1$ and it can be achieved with $\pi_{L}>\frac{y_{H}-R}{y_{H}-y_{L}}$. However, this can not be equilibrium because $d=1$ implies $\pi_{L}=0$ since $F\left(y_{H}, d=1\right)>F\left(y_{L}, d=1\right)$.

b) $\left(\mathrm{y}_{\mathrm{H}}-\mathrm{y}_{\mathrm{H}}\right) \pi_{\mathrm{H}}+\left(\mathrm{y}_{\mathrm{H}}-\mathrm{y}_{\mathrm{L}}\right) \pi_{\mathrm{L}}<\mathrm{y}_{\mathrm{H}}-\mathrm{R}_{\mathrm{M}}$.

This implies that $d=0$ and it can be achieved with $\pi_{L}<\frac{y_{H}-R}{y_{H}-y_{L}}$. However, this can not be equilibrium because $\mathrm{d}=0$ implies $\pi_{\mathrm{L}}=1$ since $\mathrm{F}\left(\mathrm{y}_{\mathrm{H}}, \mathrm{d}=0\right)<\mathrm{F}\left(\mathrm{y}_{\mathrm{L}}, \mathrm{d}=0\right)$.

c) $\left(\mathrm{y}_{\mathrm{H}}-\mathrm{y}_{\mathrm{H}}\right) \pi_{\mathrm{H}}+\left(\mathrm{y}_{\mathrm{H}}-\mathrm{y}_{\mathrm{L}}\right) \pi_{\mathrm{L}}=\mathrm{y}_{\mathrm{H}}-\mathrm{R}_{\mathrm{M}}$.

This implies that $d=d_{M}$ and that the lender's best reaction is to randomize over $y_{H}$ and $\mathrm{y}_{\mathrm{L}}$. 
Note that any $\mathrm{d}$ different from $\mathrm{d}_{\mathrm{M}}, 1$ and 0 is not possible in equilibrium because: $0<\mathrm{d}<\mathrm{d}_{\mathrm{M}}$ implies $\pi_{\mathrm{L}}=1$, with $\overline{\mathrm{R}}=\mathrm{y}_{\mathrm{L}}$ for sure, but then the borrower would choose $\mathrm{d}=\mathrm{l}$;

$\mathrm{l}>\mathrm{d}>\mathrm{d}_{\mathrm{M}}$ implies $\pi_{\mathrm{H}}=1$, with $\overline{\mathrm{R}}=\mathrm{y}_{\mathrm{H}}$ for sure, but then the borrower would choose $\mathrm{d}=0$.

This conclusion certifies that the lender does not choose to randomize over more than two renegotiation offers and that the unique equilibrium is in mixed strategy.

There is no equilibrium with the borrower defaulting when indifferent. Consider any candidate for such an equilibrium. The lender will find it advantageous to cut the charge by $\varepsilon$, increasing his profits.n

\section{BIBLIOGRAPHY}

AGHION, P.; DEWATRIPONT, M.; REY, P. On renegotiation design. European Economic Review 34, p. 322-329, 1990.

. Renegotiation design with unverifiable information. Econometrica 62, p. 257-282, March 1994.

AGHION, P.; BOLTON, P. An incomplete contracts approach to financial contracting. Review of Economic Studies 59, p. 473-494, 1992.

BESANKO, D. Competitive equilibrium in the credit market under asymmetric information. Journal of Economic Theory 42, p. 167-182, 1987.

BESTER, $\mathrm{H}$. The role of collateral in a model of debt renegotiation. Journal of Money Credit and Banking 26, p. 72-86, February 1994.

BOLTON, P. Renegotiation and the dynamics of contract design. European Economic Review 34, p. 303-310, 1990.

DEWATRIPONT, M.; MASKIN, E. Contract renegotiation in models of asymmetric information. European Economic Review 34, p. 311-321, 1990.

FUDENBERG, D.; TIROLE, J. Moral hazard and renegotiation in agency contracts. Econometrica 58, p. 1279-1319, November 1990.

. Game theory. Cambridge, Massachusetts: The MIT Press, 1991.

GALE, D.; HELLWIG, M. Incentive-compatible debt contracts: to one-period problem. Review of Economic Studies 52, p. 647-663, 1985.

HART, O.; MOORE, J. Incomplete contracts and renegotiation. Econometrica 56, p. 755-785, July 1988.

Default and renegotiation: a dynamic model of debt. Havard Business School, 1989. Mimeografado. 
KAHN, C.; HUBERMAN, G., Limited contract enforcement and strategic renegotiation. The American Economic Review 78, p. 471-484, June 1988a.

. Default, foreclosure, and strategic renegotiation. University of Illinois at Urbana-Champaign, 1988b. Mimeografado.

KAHN, C.; YAVAS, A. The economic role of foreclosures. Journal of Real State Finance and Economics 8, p. 35-51, 1994.

KRASA, S.; VILLAMIL, A. P. Contractual enforcement as a decision variable. University of Illinois at Urbana-Champaign, 1995. Mimeografado.

LAFFONT, J.; TIROLE, J. Adverse selection and renegotiation in procurement. Review of Economic Studies 57, p. 597-625, 1990.

MYERSON, R. B. Game theory: analysis of conflict. Cambridge, Massachusetts: Harvard University Press, 1991.

TOWNSEND, R. M. Optimal contracts and competitive markets with costly state verification. Journal of Economic Theory 21, p. 265-293, 1979.

WILLIAMSON, S. D. Costly monitoring, loan contracts, and equilibrium credit rationing. The Quarterly Joumal of Economics, p. 135-145, February 1987.

The author is grateful to CNPq for financial support and to Charles Khan for valuable comments on earlier version, any omission is my fault.

e-mail: pjneto@sec.secrel.com.br

(Recebido em novembro de 2001. Aceito para publicação em abril de 2005). 